\title{
Research on Project Teaching of the Course Automobile Electronic and Electrical Equipment
}

\author{
Xiao Mi \\ School of Automobile, Linyi University \\ Linyi, China \\ e-mail: mixiao@lyu.edu.cn
}

\author{
Peijiang Chen \\ School of Automobile, Linyi University \\ Linyi, China \\ e-mail: chenpeijiang@lyu.edu.cn
}

\begin{abstract}
This research was intended to apply the project teaching method to the practice teaching of the course Automobile Electronic and Electrical Equipment. We discussed the respective duty and way of act of the teachers and students in the process of the project teaching method. We designed totally 11 projects with respective learning objectives of different automobile electrical systems for the project teaching of the course Automobile Electronic and Electrical Equipment. Through the recent years' practice of the project teaching method applied on this course, we define four stages of this teaching process including project task setting, project plan making, implementation of the subject and project evaluation and summary. It is proved that project teaching method is the most effective way to cultivate students' comprehensive quality and is able to arouse students' learning interest and innovation ability. At the same time it is also able to cultivate students' analysis ability, adaptability, communication ability and cooperation ability.
\end{abstract}

Keywords- project teaching; teaching method; practice; automobile electronic and electrical equipment; application

\section{INTRODUCTION}

Project teaching is becoming more and more popular in recent years. Project teaching is also called behaviororiented teaching. It is based on the development of the student. It aims to cultivate the ability of explore and practice of the students. It is a teaching activity performed by both teachers and students.

The teachers are in charge of making the project and plan with practical meaning and organize the students to design their own implementation schedule for the project.

The students are able to study and practice all by themselves. That will achieve the object of cultivating the ability of explore and practice of the students. The project teaching is able to bridge the theory knowledge and practice knowledge effectively and enforce the interactivity between the teachers and students.

It also could stimulate the study interest and innovation ability of the students. Moreover, it also could cultivate students' analysis ability, strain capacity, communication ability and cooperation ability.

Unlike the traditional teaching method, the project teaching is bidirectional rather than unidirectional. The stimulation way is based on the inner motivation and lasting rather than forced and unabiding.

The characteristic of the project teaching is as follows.
(1) Practicalness

The project has a close contact with the reality world. The study process of the students is more clearly aimed and practical.

(2) Autonomy

The opportunity of choosing the content and demonstration way based on the students' own interest is provided.

The students are able to study more freely and on their willing. By that, the creative ability of the students is developed.

(3) Expansibility

The combination of the long term and short term project composes the cognition process to achieve the education object.

(4) Comprehensiveness

The project teaching also has the characteristics of subject overlapping and application of comprehensive ability.

(5) Openness

It is reflected in the diversity and selectivity of the way, method, demonstration and evaluation explored by the students around the subject.

(6) The characteristic of the evaluation

The evaluation of the project teaching focuses on the ability development process in project activity.

The content includes the performance of students in participating each link of the project activity and the quality of homework.

\section{THE DESIGN OF THE PROJECT FOR THE COURSE}

\section{A. The Trainning Objective of the course Automobile electronic and electrical equipment}

With the rapid development of the automobile technology, the electrical and electronics system of the automobile is becoming more and more complex.

The control circuit of the automotive components is more complicated, such as automotive head light control system, infrared rain-sensing wipers control system, button start control system and automatic car backing control system.

It requires the automobile professional design and maintenance technician to master fund of knowledge of automobile electrical and electronics system and diagnosis technology of the latest automobile components. 
The strong abstract thinking ability, logical analyzing ability and self-learning ability are also necessary for the automobile technician. By the study of the course, the students should achieve the following objectives in the aspects of knowledge and practical skill.

(1) Understanding the application of all kinds of electrical and electronics components in a modern automobile.

(2) The ability to diagnose the electrical and electronics components in a modern automobile.

(3) The ability to analyze and diagnose the integrated circuit performance.

(4) The ability to design simple electrical and electronics circuit.

(5) Understanding the latest development of the automobile electrical and electronics system.

\section{B. The Project Design of the course Automobile electrical and electronics sysytem}

The project design of the course is demonstrated in Table I.

TABLE I. PROJECT DESIGN OF COURSE

\begin{tabular}{|c|c|c|}
\hline $\begin{array}{c}\text { Project } \\
\text { Number }\end{array}$ & Project Name & Learning Objectives \\
\hline QD1 & $\begin{array}{l}\text { Automobile Alternator } \\
\text { Assemble, Disassemble } \\
\text { and Diagnosis }\end{array}$ & $\begin{array}{l}\text { 1. The Assemble and } \\
\text { Disassemble of the Automobile } \\
\text { Alternator } \\
\text { 2. The Operation Principal and } \\
\text { Basic Structure of the } \\
\text { Automobile Alternator } \\
\text { 3. The Repair and Diagnosis } \\
\text { method of the Automobile } \\
\text { Alternator }\end{array}$ \\
\hline QD2 & $\begin{array}{l}\text { Automobile Starter } \\
\text { Assemble, Disassemble } \\
\text { and Diagnosis }\end{array}$ & $\begin{array}{l}\text { 1. The Assemble and } \\
\text { Disassemble of the Automobile } \\
\text { Starter } \\
\text { 2. The Operation Principal and } \\
\text { Basic Structure of the } \\
\text { Automobile Starter } \\
\text { 3. The Repair and Diagnosis } \\
\text { method of the Automobile } \\
\text { Starter }\end{array}$ \\
\hline QD3 & $\begin{array}{lr}\text { Automobile } & \text { Ignition } \\
\text { System } & \text { Assemble, } \\
\text { Disassemble } & \text { and } \\
\text { Diagnosis } & \end{array}$ & $\begin{array}{l}\text { 1. The Assemble and } \\
\text { Disassemble of the Automobile } \\
\text { Ignition System } \\
\text { 2. The Operation Principal and } \\
\text { Basic Structure of the } \\
\text { Automobile Ignition System } \\
\text { 3. The Repair and Diagnosis } \\
\text { method of the Automobile } \\
\text { Ignition System }\end{array}$ \\
\hline QD4 & $\begin{array}{lr}\text { Automobile } & \text { Lighting } \\
\text { and Signal } & \text { System } \\
\text { Diagnosis } & \end{array}$ & $\begin{array}{l}\text { 1. The Use and Adjustment } \\
\text { method of the Automobile } \\
\text { Lighting and Signal System } \\
\text { 2. The Operation Principal and } \\
\text { Basic Structure of the } \\
\text { Automobile Lighting and } \\
\text { Signal System } \\
\text { 3. The Repair and Diagnosis } \\
\text { method of the Automobile } \\
\text { Lighting and Signal System }\end{array}$ \\
\hline QD5 & $\begin{array}{l}\text { Automobile Auxiliary } \\
\text { Electrical Equipment } \\
\text { System Diagnosis }\end{array}$ & $\begin{array}{l}\text { 1. The Use and Adjustment } \\
\text { method of the Automobile } \\
\text { Auxiliary Electrical Equipment } \\
\text { System } \\
\text { 2. The Operation Principal and } \\
\text { Basic Structure of the } \\
\text { Automobile Auxiliary } \\
\text { Electrical Equipment System }\end{array}$ \\
\hline
\end{tabular}

\begin{tabular}{|c|c|c|}
\hline $\begin{array}{l}\text { Project } \\
\text { Number }\end{array}$ & Project Name & Learning Objectives \\
\hline & & $\begin{array}{l}\text { 3. The Repair and Diagnosis } \\
\text { method of the Automobile } \\
\text { Auxiliary Electrical Equipment } \\
\text { System }\end{array}$ \\
\hline QD6 & $\begin{array}{l}\text { Engine Manage System } \\
\text { Diagnosis }\end{array}$ & $\begin{array}{l}\text { 1. The Use and Adjustment } \\
\text { method of the Engine Manage } \\
\text { System } \\
\text { 2. The Operation Principal and } \\
\text { Basic Structure of the Engine } \\
\text { Manage System } \\
\text { 3. The Repair and Diagnosis } \\
\text { method of the Engine Manage } \\
\text { System }\end{array}$ \\
\hline QD7 & $\begin{array}{l}\text { Automobile Automatic } \\
\text { Transmission Diagnosis }\end{array}$ & $\begin{array}{l}\text { 1. The Use and Adjustment } \\
\text { method of the Automobile } \\
\text { Automatic Transmission } \\
\text { 2. The Operation Principal and } \\
\text { Basic Structure of the } \\
\text { Automobile Automatic } \\
\text { Transmission } \\
\text { 3. The Repair and Diagnosis } \\
\text { method of the Automobile } \\
\text { Automatic Transmission }\end{array}$ \\
\hline QD8 & $\begin{array}{lr}\text { Automobile } & \text { Electric } \\
\text { Power } & \text { Steering } \\
\text { Diagnosis } & \end{array}$ & $\begin{array}{l}\text { 1. The Use and Adjustment } \\
\text { method of the Automobile } \\
\text { Electric Power Steering } \\
\text { 2. The Operation Principal and } \\
\text { Basic Structure of the } \\
\text { Automobile Electric Power } \\
\text { Steering } \\
\text { 3. The Repair and Diagnosis } \\
\text { method of the Automobile } \\
\text { Electric Power Steering }\end{array}$ \\
\hline QD9 & $\begin{array}{lr}\text { Automobile } & \text { Anti-lock } \\
\text { Braking } & \text { System } \\
\text { Diagnosis } & \end{array}$ & $\begin{array}{l}\text { 1. The Use and Adjustment } \\
\text { method of the Automobile } \\
\text { Anti-lock Braking System } \\
\text { 2. The Operation Principal and } \\
\text { Basic Structure of the } \\
\text { Automobile Anti-lock Braking } \\
\text { System } \\
\text { 3. The Repair and Diagnosis } \\
\text { method of the Automobile } \\
\text { Anti-lock Braking System }\end{array}$ \\
\hline QD10 & $\begin{array}{l}\text { Automobile } \\
\text { Electronic } \\
\text { Control Suspension } \\
\text { System Diagnosis }\end{array}$ & $\begin{array}{l}\text { 1. The Use and Adjustment } \\
\text { method of the Automobile } \\
\text { Electronic Control Suspension } \\
\text { System } \\
\text { 2. The Operation Principal and } \\
\text { Basic Structure of the } \\
\text { Automobile Electronic Control } \\
\text { Suspension System } \\
\text { 3. The Repair and Diagnosis } \\
\text { method of the Automobile } \\
\text { Electronic Control Suspension } \\
\text { System }\end{array}$ \\
\hline QD11 & $\begin{array}{l}\text { Automobile Entire } \\
\text { Circuitry Diagnosis }\end{array}$ & $\begin{array}{l}\text { 1. The Reading and Circuit } \\
\text { Diagnosis of Different } \\
\text { Automobile Manufacturer } \\
\text { Circuit Map } \\
\text { 2. The Operation Principal and } \\
\text { Basic Structure of Different } \\
\text { Automobile Circuit } \\
\text { 3. The Repair and Diagnosis } \\
\text { method of Different } \\
\text { Automobile Circuit }\end{array}$ \\
\hline
\end{tabular}

\section{The IMPLEMENTATION OF PROJECT TEACHING}

The project teaching is generally composed of four stages including project task setting, making project plan, implementation of the project, project evaluation and summary. 


\section{A. The Stage of Project Task Setting}

The teachers should set one or more project tasks according teaching content, teaching objectives, teaching conditions, teaching object and demands of actual production. The project task is required for strong maneuverability and applicability. After the subject task is set, the students are supposed to apply their knowledge and enhance practical operating abilities during the process of task executing.

\section{B. The Stage of Making Project Plan}

The project plan is made by students according to the requirement of project task. The plan should be operated after the demonstration in class and be approved by the classmates and teacher. The project plan can be improved through the demonstration and communication. The teacher also could provide guidance to make the students' thought more clearly. In this stage, the students make and demonstrate project plan by communication and mutual inspiration and their language competence, logical thinking, innovation ability, group cooperation capacity and sociability are enhanced.

\section{The Stage of Implementation of the Project}

After a clear division of labor in the team, the project comes into operation. All the team members gather information and apply theoretical knowledge to analyze circuit. The students' creative capability is well exerted through team cooperation and mutual assessment and the learning interest is well aroused.

\section{The Stage of Project Evaluation and Summary}

The students and teacher discuss together on the problems during the implementation of project. The teacher guides students to analyze the cause of those problems and discuss together to provide the method to solve the problem. The rectification summary is supposed to be repeated several times to make good preparation for the next round implementation of the subject. The analysis ability, design ability and application ability of the students are improved.

Take the project QD4 Automobile Lighting and Signal System Diagnosis as example to discuss the concrete implement process of project teaching.

The teacher divides the students into four to six teams. Then the project task is assigned. The assignment book is demonstrated in Table II.

Then all the students carry out the project according the assignment book.

\section{CONCLUSIONS}

By the practice of applying project teaching method on the course Automobile Electronic and Electrical Equipment, it is proved that project teaching method is the most effective way to cultivate students' comprehensive quality and is able to arouse students' learning interest and innovation ability.

At the same time it is also able to cultivate students' analysis ability, adaptability, communication ability and cooperation ability.

\section{ACKNOWLEDGMENT}

This work was supported by the Adult Higher Education Teaching Reform and Development Policy Research Project of Shandong, China, the Teaching Reform Project of Linyi University (No. 2014016), and the Teaching Quality Engineering Project of Linyi University in 2014.

\section{TABLE II. ASSIGNMENT BOOK}

\begin{tabular}{|c|c|}
\hline Project Name & Automobile Lighting and Signal System Diagnosis \\
\hline $\begin{array}{l}\text { Learning } \\
\text { Objectives }\end{array}$ & $\begin{array}{l}\text { 1. The Use and Adjustment method of the } \\
\text { Automobile Lighting and Signal System } \\
\text { 2. The Operation Principal and Basic Structure of } \\
\text { the Automobile Lighting and Signal System } \\
\text { 3. The Repair and Diagnosis method of the } \\
\text { Automobile Lighting and Signal System }\end{array}$ \\
\hline $\begin{array}{c}\text { Implementation } \\
\text { Step }\end{array}$ & $\begin{array}{l}\text { 1. The Representation of the Project Task } \\
\text { Objective and Requirement and assignment of the } \\
\text { task. } \\
\text { 2. Team Discussion. Analyze the circuit map of } \\
\text { the lighting and signal system. Connect the head }\end{array}$ \\
\hline $\begin{array}{c}\text { Implementation } \\
\text { Step }\end{array}$ & $\begin{array}{l}\text { lights and signal lights with wiring according to } \\
\text { the circuit map. Diagnose the cause of head light } \\
\text { not bright, short circuit, head light dim and signal } \\
\text { light failure. Make the project plan. } \\
\text { 3. The Implementation of the project according to } \\
\text { the plan. } \\
\text { 4. The Demonstration of the Learning Outcomes } \\
\text { and Self-assessment. } \\
\text { 5. The mutual assessment and summary. }\end{array}$ \\
\hline $\begin{array}{c}\text { Task } \\
\text { Requirement }\end{array}$ & $\begin{array}{l}\text { 1. Connect the Automobile Lighting and Signal } \\
\text { System Correctly } \\
\text { 2. Students could diagnose common faut of the } \\
\text { Automobile Lighting and Signal System Correctly } \\
\text { 3. The proper use of various testing instruments }\end{array}$ \\
\hline $\begin{array}{c}\text { Examination and } \\
\text { Evaluation }\end{array}$ & $\begin{array}{l}\text { 1. Every team would demonstrate their wiring } \\
\text { connection of the lighting and signal system and } \\
\text { explain in detail about how to diagnose the } \\
\text { common fault of the lighting and signal system. } \\
\text { 2. Every team assesses and summarizes their own } \\
\text { performance. Think about whether they finish the } \\
\text { task, are there some problems, how to improve and } \\
\text { what experience they get. } \\
\text { 3. All the teams carry out mutual assessment. } \\
\text { Point out each team's advantage and disadvantage } \\
\text { and make contrast and comparison. Communicate } \\
\text { and learn from each other. } \\
4 \text {. The Evaluation by Teacher. On one hand, it is } \\
\text { based on every team's performance in the subject } \\
\text { implementation. On the other hand, it is also based } \\
\text { on the performance of team members cooperation, } \\
\text { self-assessment and mutual assessment and team } \\
\text { learning outcomes demonstration. } \\
5 \text {. The Summary of the Project Learning Process } \\
\text { by Teacher. The teacher would give both the } \\
\text { praise and criticism based on every team's overal } \\
\text { performance. }\end{array}$ \\
\hline
\end{tabular}

\section{REFERENCES}

[1] ZHANG Yun-hua. Project Teaching in Automotive Electronic Technology $[\mathrm{J}]$. Journal of Guangdong Communications Polytechnic, 2013,12(1):64-67.

[2] LIU Yan-li. Practice of Project Approach in Vocational High School "Automotive Electrical and Electronic" Teaching [D]. Huhehaote China: Neimenggu Normal University, 2014.

[3] William Heard Kilpatrick. The Project Method [M]. Montana USA: Kessinger Publishing, 2010.

[4] ZHANG Xiang-wen. Discussion about the Reform of "Automobile Electronic Technology" [J]. Higher Education Forum, 2008,2(1): 104-106. 
[5] WANG Dong-liang. Application of Integrated Teaching of Theory and Practice in Automobile Electric Equipment and Maintenance [J]. Journal of Nanjing Institute of Industry Technology, 2010,10(4):81-83.

[6] WANG Kui-yang, TANG Jin-hua. Application and Study of Behavior-oriented Teaching Approach to "Automotive Electrical and Electronic Control Technology" [J]. Journal of Jiangsu Teachers University of Technology Communication of Vocational Education, 2009,24(2):89-92.
[7] V A W Hillier. Fundamentals of Automotive Electronics [M]. London: Century Hutchinson Ltd, 1987.

[8] Tom Denton. Automobile Electrical \& Electronic Systems [M]. London: Edward Arnold, 1995.

[9] Ken Layne. Automotive Engine Performance [M]. Englewood Cliffs, New Jersey: Regents/Prentice Hall, 1993.

[10] B. H. Dwiggins, E. F. Mahoney. Automotive Electricity and Electronics [M]. Englewood Cliffs, New Jersey: Prentice Hall, 1996. 